\title{
Functional significance of triazine-herbicide resistance in defence of Senecio vulgaris against a rust fungus
}

\author{
Daniel Salzmann ${ }^{1}$, Richard J. Handley², Heinz Müller-Schärer* \\ Department of Biology, Unit of Ecology and Evolution, University of Fribourg, Chemin du Musée 10, 1700 Fribourg, Switzerland
}

\begin{abstract}
We investigated the functional significance of plant performance (dry mass, photosynthesis) in plant defence (resistance and tolerance) against pathogen infection, and potential negative cross-resistance between herbicide resistance and plant defence against disease. We compared isonuclear triazine-herbicide-resistant (TR) and -susceptible (TS) biotypes of Senecio vulgaris, in the presence and absence of infection by the rust Puccinia lagenophorae. In a growth chamber study with two reduced irradiance levels, rust infection had a severe effect on plant performance with infected plants having 55\% less dry mass and 54\% reduced whole-plant photosynthesis than non-infected plants. The TR biotype was more susceptible (reduced resistance) to the pathogen, but the biotypes did not differ in their ability to compensate for rust infection (tolerance). TR plants were less productive than TS plants when grown non-shaded (ca. 10\% full sunlight) but not when shaded (ca. 5\% full sunlight). This is especially important for situations, where S. vulgaris grows under the crop canopy (e.g. in maize). Here, very low light levels might contribute to a numerical increase of TR relative to TS plants even when only occasionally treated with triazine. Whole-plant photosynthesis was reduced by $21 \%$ in TR plants as compared to the TS biotype, and by $59 \%$ in plants grown in the shaded as compared to the non-shaded treatment. When whole-plant photosynthesis values were corrected for the estimated leaf area of plants, we found no significant variation between biotypes, shade treatments or rust treatments. In experimental mixed TR:TS field populations, the proportion of TR plants decreased more rapidly in rust-infected populations than uninfected. This finding, together with the lower resistance in the TR than the TS biotype to the rust fungus observed in the growth chamber experiment, may indicate negative cross-resistance, which is a potential tool in the management of herbicide-resistant weeds.
\end{abstract}

\section{Zusammenfassung}

Wir untersuchten die funktionelle Bedeutung der Pflanzenleistung (Biomasse, Photosynthese) für die Pflanzenverteidigung (Resistenz und Toleranz) gegenüber einer Pathogeninfektion, sowie die Möglichkeit einer negativen Kreuzresistenz zwischen Herbizidresistenz und Pflanzenverteidigung gegenüber Pathogenen. Wir verglichen hierzu

\footnotetext{
${ }^{*}$ Corresponding author. Tel.: +4126300 8835; fax: + 41263009698.

E-mail address: heinz.mueller@unifr.ch (H. Müller-Schärer).

${ }^{1}$ Current address: Hutersbiel 9, CH-3904 Naters, Switzerland.

${ }^{2}$ Current address: Centre for Ecology, Evolution and Conservation, School of Biological Sciences, University of East Anglia, Norwich NR4 7TJ, UK.
} 
isonukleare Triazinherbizid-resistente (TR) und -empfindliche (TS) Biotypen von Senecio vulgaris, mit und ohne Infektion durch den Rostpilz Puccinia lagenophorae.

In einer Klimakammer-Studie mit zwei reduzierten Beleuchtungsstufen hatte Rostpilzinfektion einen starken Einfluss auf die Pflanzenleistung: infizierte Pflanzen hatten 55\% weniger Biomasse als nicht-infizierte Pflanzen, und eine um 54\% reduzierte Gesamt-Pflanzen-Photosyntheserate. Der TR-Biotyp reagierte empfindlicher auf Pathogeninfektion (reduzierte Resistenz), aber die Biotypen unterschieden sich nicht in ihrer Fähigkeit, für Rostpilzinfektion zu kompensieren (Toleranz). Die TR-Pflanzen waren weniger produktiv als die TS-Pflanzen, wenn diese unbeschattet (ca. 10\% volles Sonnenlicht) wuchsen, jedoch nicht, wenn sie beschattet (ca. 5\% volles Sonnenlicht) waren. Dies ist von besonderer Bedeutung für Situationen, bei denen S. vulgaris unter Kulturpflanzen (z. B. im Maisanbau) wächst, wo die sehr geringe Lichtintensität zu einer numerischen Zunahme von TR-Pflanzen auch bei nur gelegentlicher Applikation von Triazin führen kann. Die Gesamt-Pflanzen-Photosynthese war bei TR-Pflanzen um 21\% reduziert im Vergleich zum TS-Biotyp, und um 59\% für beschattete im Vergleich zu unbeschatteten Bedingungen. Wenn die Werte für die Gesamt-Pflanzen-Photosynthese jedoch für die geschätzte Pflanzen-Blattfläche korrigiert wurden, fanden wir keine signifikanten Unterschiede mehr zwischen Biotypen, sowie zwischen den Beschattungs- und den Rostpilzbehandlungen. In experimentellen, gemischten TR:TS Feldpopulationen nahm der relative Anteil der TR-Pflanzen in den Rostpilz-infizierten Populationen schneller ab als in den Kontrollpopulationen. Dieses Resultat, zusammen mit der in der Klimakammer-Studie beobachteten reduzierten Resistenz gegenüber dem Rostpilzbefall des TR- im Vergleich zum TS-Biotypen weist auf eine negative Kreuzresistenz hin, welche strategisch für die Bekämpfung Herbizid-resistenter Unkräuter genutzt werden kann.

Keywords: Disease; Pathogen; Tolerance; Resistance; Biocontrol; Herbicide resistance; Photosynthesis; Negative cross-resistance

\section{Introduction}

It is well established that pathogens and herbivores can exert a strong influence on the growth, reproduction and survival of their hosts (Burdon, 1987; Crawley, 1983). Plants defend themselves against attack from herbivores and pathogens by either resistance, defined as a reduction in the amount of damage they sustain by affecting the preference and performance of antagonists, or by tolerance, i.e. the ability to buffer negative effects of herbivory and disease on fitness by compensatory growth and reproduction after damage (Burdon, 1987; Strauss \& Agrawal, 1999; Tiffin, 2000). Resistance and tolerance may represent alternative forms of plant defence and may therefore be mutually exclusive adaptations to attack (Mauricio, Rausher, \& Burdick, 1997; Roy \& Kirchner, 2000).

One approach to the study of tolerance is to focus on specific putative tolerance traits, such as the release of lateral dormant buds or increases in growth and photosynthesis (Juenger \& Bergelson, 2000; Stowe, 1998), and to examine their response to damage. Mechanisms of tolerance have mainly been studied for herbivory (reviewed in Tiffin, 2000), and the role of photosynthesis in plant tolerance has predominantly been examined in defoliation studies (but see Inglese \& Paul, 2006, for pathogens).

To study the influence of photosynthesis on plant resistance and tolerance we compared triazine-herbicidesusceptible (TS) Senecio vulgaris biotypes with triazineherbicide-resistant (TR) biotypes. Application of triazine herbicides reduces photosynthesis and kills susceptible plants (Holt \& LeBaron, 1990). Triazine herbicide resistance (TR) in $S$. vulgaris is caused by a point mutation in the $p s b A$ chloroplast gene that results in a conformation change in the $D 1$ protein of photosystem II (Hirschberg, Bleecker, Kyle, McIntosh, \& Arntzen, 1984), resulting in a less efficient electron transport through photosystem II (Arntz, DeLucia, \& Jorda, 2000). The TR-mutation results in less dry mass and as much as a $20-30 \%$ reduced photosynthetic rate compared to plants with a susceptible chloroplast genome (Holt, Stemler, \& Radosevich, 1981; McCloskey \& Holt, 1990). Repeated use of herbicides leads to strong selection for resistance and has been reported in many weed species (Holt \& LeBaron, 1990; www.weedscience.org/in.asp).

As an antagonist we used the autoecious rust fungus Puccinia lagenophorae, which is supposed to originate from Australia and has become the most common pathogen of $S$. vulgaris in central Europe (Handley, Steinger, Treier, \& Müller-Schärer, 2008; Scholler, 1994). P. lagenophorae has been extensively studied because of its potential application as a biological control agent to reduce $S$. vulgaris densities in crops (Frantzen \& Hatcher, 1997; Grace \& Müller-Schärer, 2003; Müller-Schärer \& Frantzen, 1996; Paul, Ayres, \& Hallett, 1993).

Comparisons of TR and TS biotypes of $S$. vulgaris allow us to investigate potential negative cross-resistance as a trade-off between herbicide resistance and plant defence against disease. Here, we define negative crossresistance as reduced resistance (increased susceptibility), reduced tolerance, or both, in TR compared to TS plants, which may lead to an overall increased effect of the rust 
fungus on the performance of TR biotypes compared to the TS biotypes. Negative cross-resistance is a potential tool in the management of $S$. vulgaris as a weed by joint use of triazines and rust spores in an augmentative approach (Frantzen, Rossi, \& Müller-Schärer, 2002; Frantzen \& Müller-Schärer 2006; Müller-Schärer \& Frantzen, 1996; Müller-Schärer \& Rieger, 1998). In a growth chamber study using TS and TR biotypes and two levels of reduced irradiance, corresponding to situations of $S$. vulgaris infestations under a crop canopy, we examined plant resistance and tolerance to rust infection, and the role of photosynthesis to assess if the TR mutation will impair plant defence against the rust fungus. In a field experiment we specifically looked at consequences of a potential negative cross-resistance, using mixed TS and TR populations, with and without $P$. lagenophorae infection.

In these experiments, we address the following specific hypotheses: (1) The TR biotype will be less productive than TS biotype due to its reduced photosynthetic capacity, and the TR biotypes will show increased susceptibility to the rust pathogen, leading to a negative correlation between resistance to herbicide and resistance to the pathogen. (2) The TR biotypes will show a reduced level of tolerance to the rust fungus. (3) The negative effect of reduced irradiance (shading) on plant performance will be more pronounced in the TR than the TS biotype, and the effect of rust infection will be more severe under shading. (4) In mixed experimental field population the TR:TS ratio will decline in the absence of the rust, and decline even faster in its presence.

\section{Materials and methods}

\section{Study species}

S. vulgaris L. (Asteraceae), common groundsel, is a predominantly selfing, short-lived annual (Haldimann, Steinger, \& Müller-Schärer, 2003) that is common worldwide and often reported as a troublesome weed (Holm, Doll, Helm, Dancho, \& Herberger, 1997). $S$. vulgaris was the first species to evolve herbicide resistance and TR populations have subsequently become common and widespread in Europe and North America (Holt \& LeBaron, 1990). For both our growth chamber and field experiments, we used four inbred lines of $S$. vulgaris ssp. vulgaris var. vulgaris, which is the most widely distributed and predominant agricultural weedy accession (Kadereit, 1984; K. Leiss \& H. MüllerSchärer, 2001) (seeds originally provided by Jodie Hold, University of California, Riverside, USA, and subsequently maintained by selfing; see Stowe and Holt (1988)). These four lines represent two isonuclear families of each the triazine-resistant TR and -suscep- tible TS biotype. The original lines were produced by crossing TR (origin Washington) and TS (origin Oregon) parental biotypes. Reciprocal hybrids were backcrossed six times to their respective parental TS or $\mathrm{TR}$ pollen parent. The resulting two biotypes $\mathrm{R} \times \mathrm{S}_{\mathrm{BC} 6}$ and $\mathrm{S} \times \mathrm{R}_{\mathrm{BC} 6}$ contain ca. $99 \%$ of the nuclear genome of the pollen parent in a cytoplasm identical to that of the maternal parent (McCloskey \& Holt, 1990). In the following, we will only report on the TR-TS contrast with the two respective plant lines pooled.

As a natural antagonist, we used the autoecious rust fungus $P$. lagenophorae, which was accidentally introduced into France in the early 1960s, probably from Australia, where it has been first described from Lagenophora billadieri Cass. (Asteraceae). It has spread rapidly in Europe and is now the most common pathogen on $S$. vulgaris in central Europe, the UK and Ireland (Scholler, 1994). In this study only the asexual reproductive cycle of $P$. lagenophorae was used, which produces the characteristic orange-coloured aeciospores, typically between 10 and 14 days after inoculation with an aeciospore suspension. The systemic spread of infection is possible but disease build-up through dispersal of aeciospores from sporulating sori is the predominant mode of spread. Ongoing molecular analyses (RAPD, AFLP) of rust lines isolated from various European populations show a striking genetic uniformity both within and among populations (H. Müller-Schärer, unpublished).

\section{Growth chamber study}

Seeds of the four $S$. vulgaris lines (two lines each of the TR and TS biotypes) were sown in $9 \mathrm{~cm}$ plastic pots, filled with nutrient-amended peat (Floragard, TKS 2). Plants were grown individually in pots under controlled conditions with a 15/9 h (day/night) photoperiod and a $25 / 15^{\circ} \mathrm{C}$ (day/night) temperature cycle. We used a fully factorial experimental design with a shaded and nonshaded treatment and a rust inoculated and a noninoculated treatment replicated six times. Due to the limited space available the experiment was run twice with six replicates of the design in each run. The experimental design can be summarized as: 4 plant lines $\times 2$ levels of rust $\times 2$ irradiance levels $\times 2$ blocks (runs) $\times 6$ replicates. The experiment was carried out in a growth chamber at the Department of Biology, University of Fribourg, Switzerland. The growth chamber contained six moveable tables, three of which received a PPFD of $150 \pm 10 \mu \mathrm{mol} \mathrm{m}^{-2} \mathrm{~s}^{-1}$ over the waveband $400-700 \mathrm{~nm}$ (measured at bench height), provided by a combination of high-pressure sodium lamps (Osram Vialox $110 \mathrm{~W}$ NAv(SON)-E) and highpressure mercury lamps (Radium HRL $125 \mathrm{~W}$ ). This corresponds to ca. $10 \%$ full sunlight representative of 
ca. $50 \mathrm{~cm}$ above ground in a maize field. The other three tables were shaded (shade cloth, Agroflor, shading factor $50 \%$, GVZ-Bolltec $\mathrm{AG}, \mathrm{CH}$ ) reducing the PPFD to $80 \pm 10 \mu \mathrm{mol} \mathrm{m}^{-2} \mathrm{~s}^{-1}$ over the waveband $400-700 \mathrm{~nm}$, corresponding to ca. $5 \%$ full sunlight as found at ground level in a maize field (Larcher, 1994). Plants were placed in a hexagonal grid (at the centre and corner points) on the growth chamber tables at a distance of $20 \mathrm{~cm}$ from neighbours. Each table contained 16 plants (two replicates of each of eight possible genotype $\times$ rust combinations). Tables were moved around twice a week within the growth chamber, and plants were regularly exchanged among tables with the same light treatment for optimal randomization within and among treatment tables.

Plants were infected with the rust twice, once when they had six leaves and a second time 1 week later. Inoculation was achieved by applying an aqueous suspension of rust spores $(0.5 \mathrm{mg}$ aeciospores in $1 \mathrm{ml}$ distilled water) using a DeVilbiss hand atomizer. Plants not receiving the rust inoculation were sprayed with distilled water. All plants, inoculated or not, were covered with plastic bags after inoculation to allow for a $12 \mathrm{~h}$ dew period (K.A. Leiss \& H. Müller-Schärer, 2001).

Plant photosynthetic rate, whole-plant leaf area and the height of plants, from the soil surface to the apical meristem, were measured 2 weeks after the first rust inoculation. The severity of rust infection and apical height were also measured 5 weeks after the first rust inoculation. Increase in plant height was determined as the difference in apical height between measurements taken at 2 and 5 weeks after inoculation. Approximately 7 weeks after the first rust inoculation we harvested all plants and measured vegetative dry mass and the number and dry mass of capitula.

In order to understand whole-plant response, we decided to directly measure whole plant carbon fixation as this has the advantage to integrate responses across all leaves, uninfected or asymptomatic as well as infected, different leaf ages, etc. (see Appendix A for the description of the photosynthesis and leaf area measurements).

Disease severity was assessed as the proportion of leaves with disease symptoms on a plant. We found a strong positive correlation between this easy to assess measure and the average disease level based on visual disease ratings of all individual leaves (Pearson correlation coefficient, $\rho=0.92 ; P=0.0001$ ) (Pfirter \& Défago, 1998).

We consider resistance to be made up of properties that reduce the amount of rust infection that a plant sustains and operationally defined resistance as the proportion of uninfected leaves (Pilson, 2000).

We found a strong positive correlation between vegetative dry mass and capitulum number for plants from which data on capitulum number were available (Pearson correlation coefficient, $\rho=0.74 ; P=0.0001$ ), and this relationship was similar for all treatments. In subsequent analyses we used plant dry mass as a surrogate for plant fitness.

For the purpose of this study we depict tolerance by plotting plant dry mass against the proportion of rustinfected leaves on a plant.

\section{Field study}

The field study was carried out during the spring and summer of 2003 in the grounds of the University of Fribourg. We established eight experimental populations in $1.5 \mathrm{~m}^{2}$ plots laid out in a grid $(2 \times 4$ plots $)$ and separated by $2 \mathrm{~m}$ grass strips, each with equal numbers of the four biotypes. We transplanted 256 (64 of each biotype) plants randomly to each plot when they were at the 3-5 leaf stage. Plants were placed at a distance of $10 \mathrm{~cm}$ from each other. Only a few plants died and had to be replaced during the first few weeks. When plants had between four and six leaves, four of the plots (replicates) were inoculated with an aqueous suspension of rust spores ( $0.5 \mathrm{mg}$ aeciospores in $1 \mathrm{ml}$ distilled water) applied in a fine mist using a pump spray. Immediately after spraying, the plots were covered with plastic sheeting to allow for a $12 \mathrm{~h}$ dew period. Control plots were sprayed with water and were also covered with a plastic sheet. Disease in the control plots, through natural infection, was minimized by spraying with a non-selective fungicide (Maag Belrose spray (difenoconazol), which has been shown to have no affect on plant growth; S. Vogelgsang, unpublished). Diseases other than rust were not observed in the rust-infected plots which where not treated. All plots were kept covered with a netting to prevent bird or mammal damage throughout the experiment. Plots were watered regularly and weeded to avoid interspecific competition.

Three weeks after rust inoculation plant survival was recorded in all plots. Plants from the first generation (planted) were allowed to grow and set seed. The second generation was the result of natural seed set of the firstgeneration plants, as dormancy in $S$. vulgaris ssp. vulgaris var. vulgaris, the accession used in our study, is reported to be nearly absent (Kadereit, 1984; Popay \& Roberts, 1970). A recent molecular marker study at seven sites in two regions of Switzerland further showed that the three seasonal cohorts of $S$. vulgaris may simply arise from seed shed in the previous generation (Haldimann et al., 2003). Moreover, all S. vulgaris in the vicinity of our plots had been removed before the start and during our experiment, and plots had been fenced with a fine mesh to avoid cross-contaminations through seed dispersal. Plots were infected using the same method as before to ensure infection of the second 
generation. The second generation of plants in the control plots was very dense, much denser than the first generation or the inoculated plots. We therefore randomly thinned these plots to achieve a density approximately that of the infected plots to avoid potential biotype-specific mortality due to competition in the control plots, but not in the infected plots.

Sampling of the second generation was carried out when the majority of plants had six leaves. Fifty samples were taken at random positions in each plot along a transect in the form of a ' $W$ ', resulting in a total of 400 plants. One leaf per plant was removed to determine the biotype. This was done by incubating the leaves in a solution of atrazine (Gesaprim, 50\% atrazine; submerged in $10 \mathrm{ml} 100 \mu \mathrm{M}$ per Petri dish), which corresponded to $1.5 \mathrm{~kg}$ a.i. ha ${ }^{-1}$ (= normal field concentration), in the dark for a minimum of $2 \mathrm{~h}$. Following incubation leaf fluorescence was measured using a Hansatech, Plant Efficiency Analyser (Hansatech Instruments Ltd., King's Lynn, Norfolk, UK). Comparison of the chlorophyll $a$ fluorescence intensity graphs enabled us to distinguish between the TR and TS biotypes (Ahrens, Arntzen, \& Stoller, 1981).

\section{Statistical analysis}

All analysis was carried-out using the SAS System for Windows, version 8 (SAS Institute, Cary, North Carolina, USA). The variation in plant survival in the growth chamber experiment was analyzed with a Generalized Linear Model with a binomial error distribution using the GENMOD procedure. We present Likelihood Ratio Type III tests of significance. Differences between biotypes (fixed factor), rust treatments (fixed factor), shade treatments (fixed factor) and blocks (random factor) in plant dry mass, growth rate and photosynthesis were analyzed with analysis of variance using the GLM procedure in SAS. Analysis of covariance (GLM procedure), was carried out using plant dry mass data from rust-infected plants only, infection level as a covariable, and shade treatment as a fixed factor. Differences between biotypes (fixed factor), shade treatments (fixed factor) and blocks (random factor) in resistance to the rust were also analyzed using the GLM procedure in SAS using data from only the rust-infected plants. All data were first checked for normality and heteroscedasticity and appropriate transformations were used where required (Zar, 1984). In the analysis of photosynthesis two values were found to be extreme outliers (greater than the 99 percentile) and were excluded from the analysis. Differences between biotypes and treatments in plant dry mass, resistance and photosynthesis were examined with Tukey-Kramer post-hoc tests in procedure GLM. Where least squares means are given in the text these are derived from full models in the GLM procedure in SAS.
In the field study, differences between biotypes in the number of plants surviving in the first generation were tested with a Wilcoxon rank-sum test. The departure from the assumption of a 1:1 ratio of TR to TS biotype plants in the second generation was tested with a Chi-square goodness of fit test.

\section{Results}

\section{Growth chamber study}

\section{Survival}

The proportion of plants that survived to the end of the experiment was not significantly different between the TS and the TR biotypes, nor was the proportion of plants surviving different between the shaded and the non-shaded treatments, but fewer plants survived when rust infected than when non-infected (Table 1). The only significant interaction term was a strong rust by shading interaction, with the lowest plant survival being observed when the rust and shading treatments where combined (Table 1).

\section{Performance of the biotypes and effect of rust infection}

The TR biotype was $20 \%$ less productive than the TS biotype ( $p<0.01$, Fig. 1A), but there were no detectable differences between biotypes in height growth $(p>0.05)$. Plant growth was estimated as the change in height of the plants between 2 and 5 weeks after inoculation). Results were similar when using relative height growth. TR plants had a $21 \%$ reduced whole-plant photosynthesis as compared to the TS biotype $(P<0.05$, Fig. 1B), but when whole-plant photosynthesis values were

Table 1. Survival of Senecio vulgaris in the various treatments of the growth chamber experiment (proportion of plants that survived to the end of the experiment) with significance of treatment and interaction effects (generalized linear model (GENMOD SAS) with a binomial error distribution and likelihood ratio type III tests of significance) (only the rust $\times$ shading interaction was significant with $P<0.001)$

\begin{tabular}{llll}
\hline $\begin{array}{l}\text { Source of } \\
\text { variation }\end{array}$ & Category & $\begin{array}{l}\text { Mean survival } \\
\text { probability } \pm \mathrm{SE}\end{array}$ & $\chi^{2}$ \\
\hline Biotype & TS & $0.65 \pm 0.11$ & $0.19 \mathrm{~ns}$ \\
& TR & $0.70 \pm 0.10$ & \\
Shading & Shaded & $0.58 \pm 0.11$ & $0.14 \mathrm{~ns}$ \\
& Non-shaded & $0.76 \pm 0.09$ & \\
Rust & Infected & $0.37 \pm 0.10$ & $123.02 * * *$ \\
& Non-infected & $0.98 \pm 0.10$ & \\
Rust and & Infected and & $0.17 \pm 0.18$ & $11.66^{* * *}$ \\
shading & shaded & & \\
\hline$* P<0.05 ; * * P<0.01 ; * * * P<0.001$. &
\end{tabular}



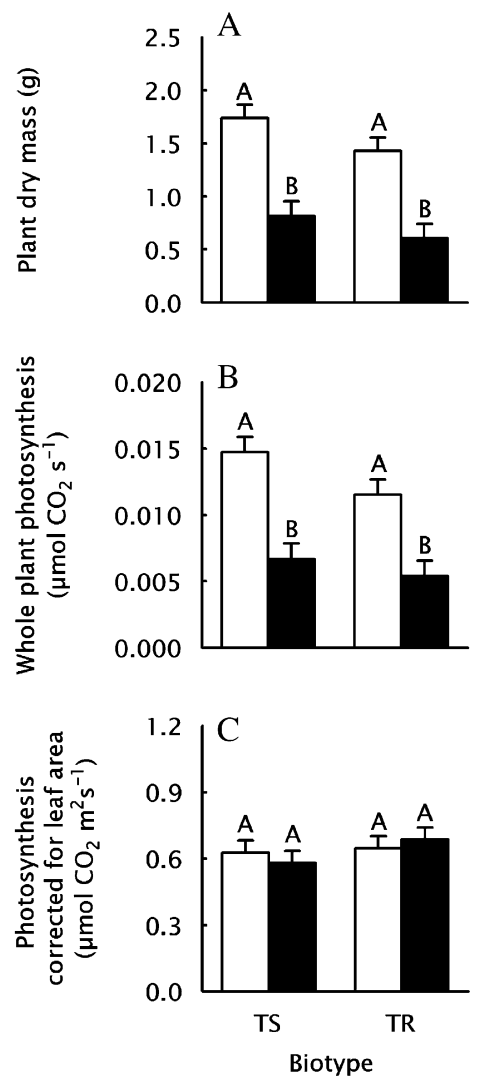

Fig. 1. Comparison of triazine-resistant (TR) and triazinesusceptible (TS) biotypes of Senecio vulgaris grown in noninfected (open bars) and in rust-infected (filled bars) plants (Mean \pm SE): (A) plant dry mass, (B) whole-plant photosynthesis, (C) photosynthesis corrected for leaf area. Means that differ at the $P<0.05$ level are labelled with different letters (Tukey-Kramer tests in proc GLM of SAS).

corrected for the estimated leaf area of plants, we found no significant variation between biotypes (Fig. 1C).

Rust infection had a severe effect on plant performance with infected plants having 55\% less dry mass than infected plants (Fig. 1A), 72\% reduced height growth $(P<0.001)$ and $54 \%$ reduced whole-plant photosynthesis (Fig. 1B), but we found no significant variation between the rust treatments once corrected for leaf area (Fig. 1C).

Overall, TR plants did not suffer more than TS plants when infected by the rust fungus, as indicated by nonsignificant biotype $\times$ rust treatment interactions for dry mass, height growth and the two photosynthesis measurements. However, resistance to the rust pathogen differed significantly between the TR and TS biotypes, with the TR biotype having 13\% less rust resistance than the TS biotype (Table 2, Fig. 2D). The negative slopes of the lines relating plant dry mass to the level of rust infection demonstrate that both biotypes undercompensate for the rust infection (Fig. 3), but the two biotypes did not differ in tolerance to the rust fungus, as indicated by the non-significant biotype $\times$ rust infection
Table 2. Results of an analysis of variance ( $F$ ratio and significance) on resistance (1 - the proportion of infected leaves) of TS and TR biotypes (biotype) of Senecio vulgaris from the Puccinia lagenophorae rust-infected treatment grown under shaded and non-shaded conditions (shade effect)

\begin{tabular}{lll}
\hline Source of variation & df & Resistance \\
\hline Block & 1 & $17.19^{* * *}$ \\
Biotype & 1 & $7.62^{* *}$ \\
Shade effect & 1 & $78.69^{* * *}$ \\
Biotype $\times$ shade & 1 & $0.36 \mathrm{~ns}$ \\
\hline
\end{tabular}

$* P<0.05 ; * * P<0.01 ; * * * P<0.001$.
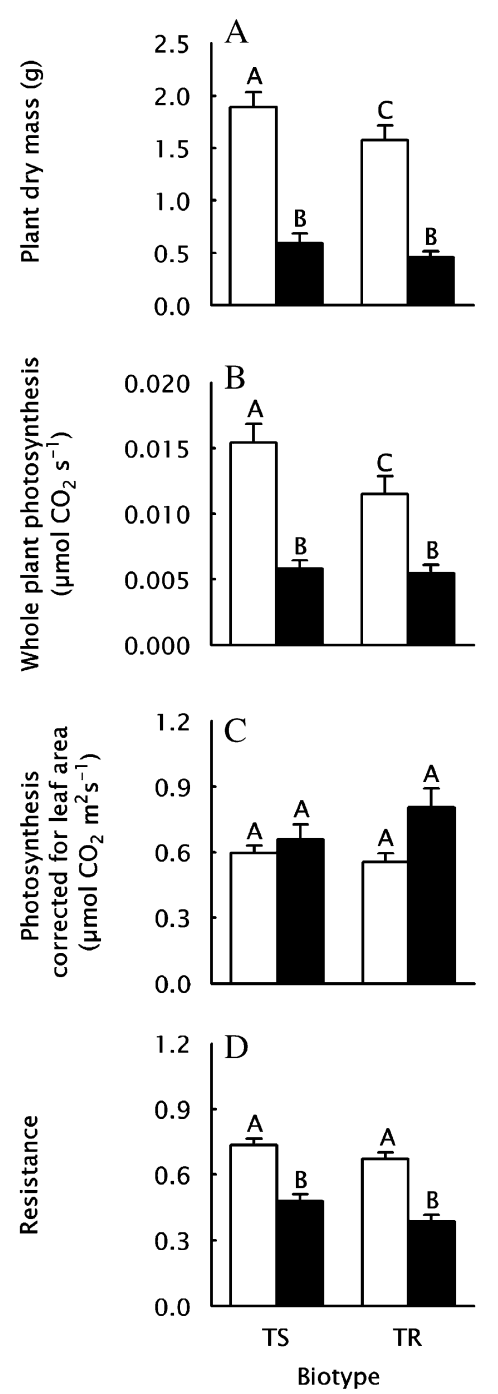

Fig. 2. Comparison of triazine-resistant (TR) and triazinesusceptible (TS) biotypes of Senecio vulgaris grown in nonshaded (open bars) and shaded (filled bars) conditions (Mean \pm SE): (A) plant dry mass, (B) whole-plant photosynthesis, (C) photosynthesis corrected for leaf area, (D) resistance to the rust fungus $P$. lagenophorae. Means that differ at the $P<0.05$ level are labelled with different letters (Tukey-Kramer tests in proc GLM of SAS). 


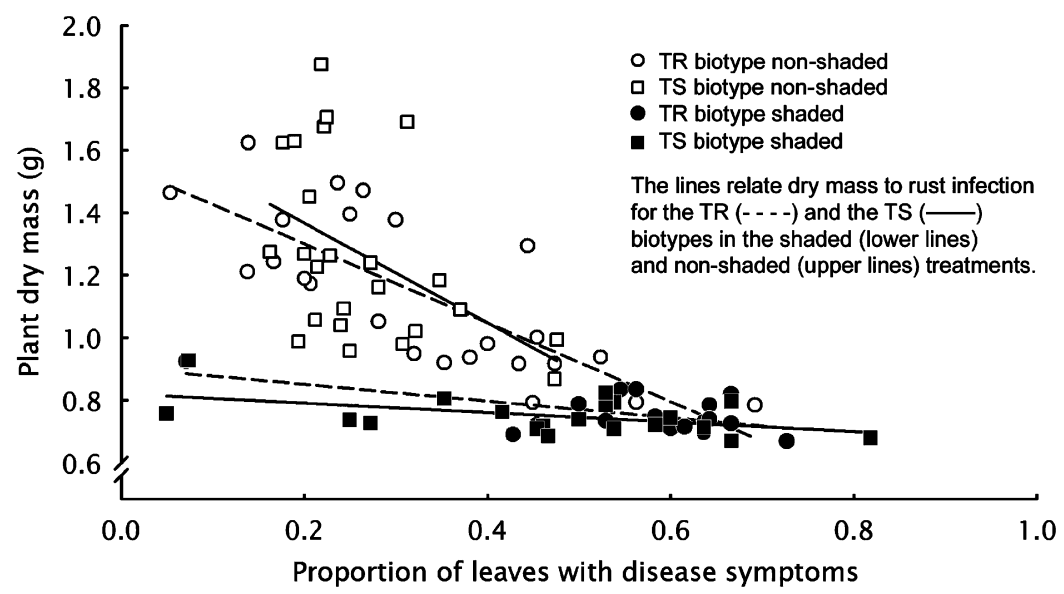

Fig. 3. Scatterplot relating plant dry mass to the proportion of rust-infected leaves on triazine-resistant (TR) and triazinesusceptible (TS) biotypes of Senecio vulgaris infected with the rust fungus Puccinia lagenophorae and grown at two different irradiance levels. The slope of the line indicates the degree to which plant dry mass is affected by rust infection.

Table 3. Results of an analysis of covariance $(F$ ratio and significance) on plant dry mass of triazine-resistant (TR) and triazine-susceptible (TS) Senecio vulgaris biotypes (biotype) grown under shaded and non-shaded conditions (shade treatment) in the growth chamber, and with Puccinia lagenophorae rust infection measured on an interval scale in the infected treatment (rust infection)

\begin{tabular}{lll}
\hline Source of variation & df & Plant dry mass \\
\hline Block & 1 & $24.44^{* * *}$ \\
Rust infection & 1 & $15.70^{* * *}$ \\
Biotype & 1 & $0.20 \mathrm{~ns}$ \\
Shade effect & 1 & $38.81^{* * *}$ \\
Rust infection $\times$ biotype & 1 & $0.04 \mathrm{~ns}$ \\
Rust infection $\times$ shade & 1 & $8.19^{* *}$ \\
Biotype $\times$ shade & 1 & $0.21 \mathrm{~ns}$ \\
Rust $\times$ biotype $\times$ shade & 1 & $0.04 \mathrm{~ns}$ \\
\hline
\end{tabular}

$* P<0.05 ; * * P<0.01 ; * * * P<0.001$.

interaction in the analysis of covariance on plant dry mass $(P>0.05$, Table 3, Fig. 3).

\section{Interactions with shading}

The shade treatment greatly reduced both dry mass by $70 \%$ (Fig. 2A) and plant height growth by $81 \%$ as compared to the non-shaded treatment. The TR biotype was less productive only when grown non-shaded but not when shaded, compared to the TS biotype (significant shade $\times$ biotype interaction; Fig. 2A), and rust infection had a smaller negative effect on growth in the non-shaded than the shaded treatment (significant rust treatment $\times$ shade treatment interaction, $P<0.05$ ).

Whole-plant photosynthesis was reduced by $59 \%$ in plants grown in the shaded compared to the nonshaded treatment $(P<0.01)$. The overall effect of the biotype $\times$ shade treatment was not significant, however, independent contrasts indicate that whole-plant photosynthesis in the TR biotype was significantly lower compared to the TS biotype in the non-shaded treatment, but not in the shaded treatment $(P<0.05)$ (Fig. 2B). When whole-plant photosynthesis values were corrected for the estimated leaf area of plants, we found no significant variation between the shade treatments (Fig. 2C).

Resistance to the rust pathogen varied significantly between the shaded and non-shaded treatments $(P<0.01)$, with shaded plants being 39\% less resistant to the rust fungus than non-shaded plants (Fig. 2D). Variation in resistance between biotypes did not depend on the shading treatment as indicated by the nonsignificant interaction of biotype $\times$ shade treatment $(P>0.05$; see also Fig. 2D). When plant height growth of the plants that survived to the end of the experiment is included as a covariable in the analysis of variance on resistance, the effect of the shade treatment is no longer significant suggesting that differences in resistance are due to the effects of these treatments on plant growth. In this analysis of covariance plant biotype is significant at $P<0.06(F=3.87, P=0.059)$ suggesting that some variation in rust resistance between biotypes is not attributable to variation in plant growth.

Biotypes did not differ in tolerance to the rust fungus within both the shaded and non-shaded treatments as indicated by the non-significant biotype $\times$ rust infection and biotype $\times$ rust infection $\times$ shade treatment interactions in the analysis of covariance on plant dry mass $(P>0.05$; Table 3, Fig. 3). The significance of the shading treatment $\times$ rust infection effect in the analysis of covariance on plant dry mass indicates that tolerance differed between the shaded and non-shaded treatments (Table 3. Fig. 3). When considered together, both 
biotypes grown in the shade were more tolerant to the rust fungus than in the non-shaded treatment as indicated by the shallower slope of the regression lines relating plant dry mass to rust infection (shade: slope \pm 1 SE, $-0.209 \pm 0.06, \quad P<0.01 ; \quad r^{2}=0.31 ;$ non-shaded: $-1.42 \pm 0.17, P<0.001 ; r^{2}=0.57$ ) (Fig. 3).

\section{Field study}

All non-inoculated plants survived during the first generation. In the rust-inoculated populations some plants of both biotypes died during the 3 weeks after rust inoculation. Five times less TR biotype plants survived than the TS biotype $(P<0.05)$ (see also Fig. 4$)$. In the second generation we found that in a sample of 400 plants (50 plants from each population) there was a significant departure from the assumption of a $1: 1$ ratio of TR to TS biotypes with the TR biotype significantly underrepresented in the sample $(P<0.001)$ (Fig. 4). In non-inoculated populations, we found on average four times fewer TR than TS plants per experimental population $(P<0.001)$ and in inoculated populations more than 15 times fewer TR than TS plants $(P=0.05)$.

\section{Discussion}

As hypothesized and consistent with earlier studies (McCloskey \& Holt, 1990; McCloskey \& Holt, 1991) the TR biotype was less productive compared to the TS biotype (Fig. 1A). Observed levels of photosynthesis, however, indicate that although whole-plant photosynthesis in the TR biotype was significantly lower compared to the TS biotype (Fig. 1B), no significant differences between biotypes became apparent, when

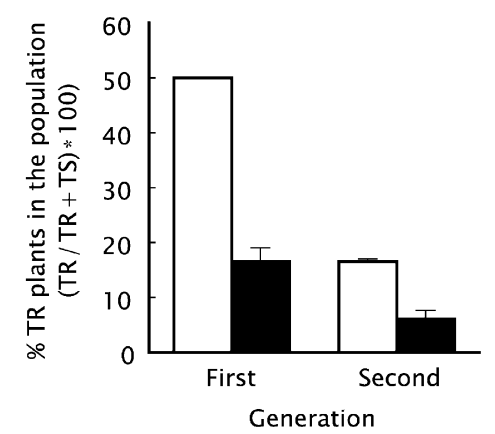

Fig. 4. Differential survival of triazine-resistant (TR) and triazine-susceptible (TS) Senecio vulgaris biotypes in mixed experimental field populations for rust-infected (filled bars) and control populations (open bars). The TR:TS ratio declines in the absence of the rust, and declines even faster in its presence, as determined 3 weeks after infection of treatment populations with rust (first generation) and in the second generation. All populations initially contained equal numbers of TR and TS plants. Mean \pm SE is given. whole-plant photosynthesis values were corrected for the estimated leaf area of plants (Fig. 1C). Thus, TS plants apparently achieve their higher production through increased allocation of resources to leaves (increased leaf area ratio, LAR), and not by increasing their photosynthetic rate per leaf area (net assimilation rate, NAR) (Shipley, 2000, 2002).

As predicted, rust infection had a severe negative effect on plant survival and dry mass with the greatest effect being seen when combined with the shade treatment (Table 1). As further hypothesized we also found the TR biotype to be less resistant to the rust fungus, but the biotypes did not differ in tolerance, and overall the TR plants did not show a significantly reduced performance (dry mass, apical height) in our growth chamber study. Our studies on the effects of shading, and measuring gas exchange and plant growth revealed further insights into the underlying complex mechanisms of our findings on plant defence in the TR and TS plants.

The observed differences in rust resistance could be mainly explained by treatment effects on plant growth, but some variation in rust resistance between biotypes remained irrespective of the difference in plant growth. Differences in whole-plant photosynthesis also mirrored the effects of the rust treatment on plant growth. We found no compensatory increase in photosynthesis once our measured values of whole-plant photosynthesis were adjusted to reflect photosynthesis per unit leaf area. This is in contrast to the findings of Murray and Walters (1992) studying rust infection on Vicia faba L., but they directly used measurements of individual leaves and found compensation in non-infected leaves of infected plants. Our measurement of whole-plant photosynthesis integrates leaves which may have reduced photosynthesis, with those that may have increased levels of photosynthesis, and we could therefore be masking compensation in uninfected tissue by using this approach. In a recent study, Inglese and Paul (2006) found small but significant compensatory photosynthesis in uninfected leaves of plants infected by $P$. lagenophorae, which confirms earlier studies (Paul \& Ayres, 1984), but complete loss of carbon fixation in infected leaves, leading to an overall decrease in mean canopy photosynthetic rate. In our own work on leaf level photosynthetic responses to rust infection, carried out under reduced irradiance levels, we did not find compensation of this kind (R. Handley \& H. MüllerSchärer, unpublished). Other studies on photosynthetic responses to rust infection have found no 'global' effect on the photosynthesis of asymptomatic leaves or asymptomatic areas of infected leaves (Robert, Bancal, Ney, \& Lannou, 2005).

We found fitness cost of TR at relatively low, but not at very low irradiance levels. Fitness costs are known to decrease at low light levels in TR biotypes of various 
species (Hart \& Stemler, 1990). Other studies have observed an increase in fitness costs in the TR biotype at low irradiance under field conditions where low light intensities were coupled with an increase in neighbour interference (Jordan, 1996). Arntz, DeLucia, and Jordan (1998) found similar fitness costs in TR biotypes of Amaranthus hybridus at low $\left(255 \mu \mathrm{mol} \mathrm{m}{ }^{-2} \mathrm{~s}^{-1}\right)$ and high $\left(1075 \mu \mathrm{mol} \mathrm{m}^{-2} \mathrm{~s}^{-1}\right)$ irradiance levels and they attribute this result to high growth temperatures. It seems that fitness costs of triazine resistance are likely to be environment dependent (Jordan, 1996). Triazine-resistant biotypes of weedy species are a particular problem in agricultural crops such as in maize cultivation, or in ornamental crops, where irradiance levels under the canopy are usually low. The fact that there is no fitness cost of the TR mutation at very low irradiance levels could contribute to the enrichment of TR plants even in crops that are only occasionally treated with triazine herbicide.

Resistance appears to be greater in the non-shaded plants because they sustain less rust infection due to greater growth in the non-shaded treatment. However, based on the data we have collected we are unable to say, whether the increased growth affects the performance of the rust. The most parsimonious explanation is that increased growth means that infected tissue makes up a smaller proportion of the non-shaded plants compared to the slow-growing shaded plants. Rust infection could reach higher levels in slower growing plants because rapid growth may allow new leaves and stems to be spatially and temporally more distant from the site of new rust spore production. This 'disease escape' cannot be regarded as a resistant mechanism (Burdon, 1987) as it is an incidental result of the environment in which the host is growing and not a characteristic of the host itself. However, it is also possible that increased growth rate in the host affects the performance of the rust.

Although biotypes did not differ in tolerance, as we hypothesized, plants grown under very low light levels (shade treatment) appeared to be more tolerant than plants grown under low light levels, i.e. non-shaded. This may be an effect of the shade treatment on plant growth and suggests that the effect of rust infection is proportional to growth and not the absolute removal of biomass. The shade treatment may also have affected the development and functioning of the rust, reducing its impact on plant physiology. The spread of infection in the shaded treatment could also have been limited by the availability of new plant tissue. Although if this were the case we might expect to see nearly complete infection and even though infections, as a proportion of leaf number, were higher in the plants grown shaded, there was uninfected tissue at the time of final harvest. The mechanism by which shading increases the compensatory ability of plants to rust infection in this study is unclear but warrants further investigation particularly as very low light levels are a common experience of crop weeds such as $S$. vulgaris.

In our field study, we observed a rapid change in the biotype composition of our experimental populations, suggesting that in rust inoculated as well as control plots, the TR biotype would disappear within a few generations (Fig. 4). This is most probably due to the reduced growth of TR plants and their being outcompeted by TS plants in mixed populations. Such a decrease in the relative frequency of TR biotypes was also observed in experimental populations of $A$. hybridus (Arntz et al., 2000). The effect of rust infection is to increase the mortality of the TR biotype compared to the TS type and may indicate that the plants with reduced photosynthetic capacity are less able to defend themselves against disease. This indeed suggests a tradeoff between triazine resistance and plant defence, i.e. negative cross-resistance, which is consistent with the results found in the growth chamber experiment, where TR plants showed increased susceptibility to the rust infection. Such increased susceptibility to antagonists has also been found in triazine-resistant $A$. hybridus to both specialist and generalist insect herbivores (Gassmann, 2005; Gassmann \& Futuyma, 2005). Negative cross-resistance has been proposed as a potential tool in the management of herbicide-resistant weeds (Gressel \& Segel, 1990; Mathiassen \& Kudsk, 1991). A combination of herbicide application with an augmentative control strategy using the rust fungus (Frantzen \& MüllerSchärer, 2006; Grace \& Müller-Schärer, 2003; MüllerSchärer \& Rieger, 1998) could prevent the enrichment of TR biotypes in the field by reducing the fitness of TR biotypes and preventing or reducing the development of resistant populations.

\section{Acknowledgements}

We would like to thank Nilgun Sailer for her extensive help during the course of these experiments, Jodie Holt (University of Riverside, CA, USA) for originally providing the seed of the four $S$. vulgaris plant lines, and Thomas Steinger, Urs Treier and Urs Schaffner for fruitful discussions and comments on the manuscript. This study was financially supported by the Swiss National Science Foundation (Grant number 3100-065356 to Heinz Müller-Schärer). 


\section{References}

Ahrens, W. H., Arntzen, C. J., \& Stoller, E. W. (1981). Chlorophyll fluorescence assay for the determination of triazine resistance. Weed Science, 29, 316-322.

Arntz, A. M., DeLucia, E. H., \& Jordan, N. (1998). Contribution of photosynthetic rate to growth and reproduction in Amaranthus hybridus. Oecologia, 117, 323-330.

Arntz, A. M., DeLucia, E. H., \& Jorda, N. (2000). From flourescence to fitness: Variation in photosynthetic rate affects fecundity and survivorship. Ecology, 81, 2567-2576.

Burdon, J. J. (1987). Diseases and plant population biology. Cambridge, UK: Cambridge University Press.

Crawley, M. J. (1983). Herbivory: The dynamics of animalplant interactions. London, UK: Blackwell.

Frantzen, J., \& Hatcher, P. E. (1997). A fresh view on the control of the annual plant Senecio vulgaris. Integrated Pest Management Reviews, 2, 77-85.

Frantzen, J., Rossi, F., \& Müller-Schärer, H. (2002). Integration of biological control of Senecio vulgaris into chemical weed control. Weed Science, 50, 787-793.

Frantzen, J., \& Müller-Schärer, H. (2006). Modeling the impact of a biocontrol agent, Puccinia lagenophorae, on interactions between a crop, Daucus carota, and a weed. Biological Control, 37, 301-306.

Gassmann, A. J. (2005). Resistance to herbicide and susceptibility to herbivores: Environmental variation in the magnitude of an ecological trade-off. Oecologia, 145, 575-585.

Gassmann, A. J., \& Futuyma, D. J. (2005). Consequences of herbivory for the fitness cost of herbicide reistance: Photosynthetic variation in the context of plant-herbivoe interactions. Journal of Evolutionary Biology, 18, 447-454.

Grace, B., \& Müller-Schärer, H. (2003). Biological control of Senecio vulgaris in carrots (Daucus carota) with the rust fungus Puccinia lagenophorae. Basic and Applied Ecology, 4, 375-384.

Gressel, J., \& Segel, L. A. (1990). Negative cross resistance a possible key to atrazine resistance management: A call for whole plant data. Zeitschrift fur Naturforschung C, 45, 470-473.

Haldimann, P., Steinger, T., \& Müller-Schärer, H. (2003). Low genetic differentiation among seasonal cohorts in Senecio vulgaris as revealed by amplified fragment length polymorphism analysis. Molecular Ecology, 12, 2541-2551.

Handley, R. J., Steinger, T., Treier, U. A., \& Müller-Schärer, H. (2008). Regional differences in exposure-time to plant disease: Testing the EICA hypothesis in a novel framework. Ecology 89(2), in print.

Hart, J. J., \& Stemler, A. (1990). Similar photosynthetic performance in low light-grown isonuclear triazine-resistant and triazine-susceptible Brassica napus L. Plant Pathology, 94, 1295-1300.

Hirschberg, J., Bleecker, A., Kyle, D. J., McIntosh, L., \& Arntzen, D. J. (1984). The molecular basis of triazineresistance in higher plant chloroplasts. Zeitschrift fur Naturforschung C, 39, 412-419.

Holm, L., Doll, F., Helm, E., Dancho, G., \& Herberger, G. (1997). Senecio vulgaris L. In World weeds: Natural histories and distribution. New York: Wiley.
Holt, J. S., \& LeBaron, H. M. (1990). Significance and distribution of herbicide resistance. Weed Technology, 4, 141-149.

Holt, J. S., Stemler, A. J., \& Radosevich, S. R. (1981). Differential light responses of photosynthesis by triazine resistant and triazine susceptible Senecio vulgaris biotypes. Plant Physiology, 67, 744-748.

Inglese, S. J., \& Paul, N. P. (2006). Tolerance of Senecio vulgaris to infection and disease caused by native and alien rust fungi. Phytopathology, 96, 718-726.

Juenger, T., \& Bergelson, J. (2000). The evolution of compensation to herbivory in scarlet gilia, Ipomopsis aggregata: Herbivore-imposed natural selection and the quantitative genetics of tolerance. Evolution, 54, 764-777.

Jordan, N. (1996). Effects of the triazine-resistance mutation on fitness in Amaranthus hybridus (smooth pigweed). Journal of Applied Ecology, 33, 141-150.

Kadereit, J. W. (1984). The origin of Senecio vulgaris (Asteraceae). Plant Systematics and Evolution, 145, 135-153.

Larcher, W. (1994). Ökophysiologie der Pflanzen. (5. Auflage). Stuttgart: Eugen Ulmer Verlag.

Leiss, K., \& Müller-Schärer, H. (2001a). Population dynamics of the annual plant Senecio vulgaris and the rust fungus Puccinia lagenophorae at ruderal and agricultural habitats. Basic and Applied Ecology, 2, 53-64.

Leiss, K. A., \& Müller-Schärer, H. (2001b). Adaptation of Senecio vulgaris (Asteraceae) to ruderal and agricultural habitats. American Journal of Botany, 88, 1593-1599.

Mathiassen, S. K., \& Kudsk, P. (1991). The response of atrazine-resistant and susceptible biotypes of Chenopodium album to other herbicides assessed by a parallel-line assay. Mededelingen van de Faculteit Landbouwwetenschappen. Rijksuniversiteit Gent, 56, 695-699.

Mauricio, R., Rausher, M. D., \& Burdick, D. S. (1997). Variation in the defense strategies of plants: Are resistance and tolerance mutually exclusive. Ecology, 78, 1301-1311.

McCloskey, W. B., \& Holt, J. S. (1990). Triazine resistance in Senecio vulgaris parental and nearly isonuclear backcrossed biotypes is correlated with reduced productivity. Plant Physiology, 92, 954-962.

McCloskey, W. B., \& Holt, J. S. (1991). Effect of growth temperature on biomass production of nearly isonuclear triazine-resistant and -susceptible common groundsel (Senecio vulgaris). Plant Cell and Environment, 14, 699-705.

Murray, D. C., \& Walters, D. R. (1992). Increased photosynthesis and resistance to rust infection in upper, uninfected leaves of rusted broad bean (Vicia faba L.). New Phytologist, 120, 235-242.

Müller-Schärer, H., \& Frantzen, J. (1996). An emerging system management approach for biological weed control in crops: Senecio vulgaris as a research model. Weed Research, 36, 483-491.

Müller-Schärer, H., \& Rieger, S. (1998). Epidemic spread of the rust fungus Puccinia lagenophorae and its impact on the competitive ability of Senecio vulgaris in celeriac during early development. Biocontrol Science and Technology, 8, 59-72.

Paul, N. D., \& Ayres, P. G. (1984). Effects of rust and postinfection drought on photosynthesis, growth and water relations in groudsel. Plant Pathology, 33, 561-569. 
Paul, N. D., Ayres, P. G., \& Hallett, S. G. (1993). Mycoherbicides and other biocontrol agents for Senecio spp. Pesticide Science, 37, 323-329.

Pfirter, H. A., \& Défago, G. (1998). The potential of Stagonospora sp. as a mycoherbicide for field bindweed. Biocontrol Science and Technology, 8, 93-101.

Pilson, D. (2000). The evolution of plant response to herbivory: Simultaneously considering resistance and tolerance in Brassica rapa. Evolutionary Ecology, 14, 457-489.

Popay, A. I., \& Roberts, E. H. (1970). Factors involved in the dormancy and germination of Capsella bursa-pastoris (L.) Medik and Senecio vulgaris L. Journal of Ecology, 58, 103-122.

Robert, C., Bancal, M. O., Ney, B., \& Lannou, C. (2005). Wheat leaf photosynthesis loss due to leaf rust, with respect to lesion development and leaf nitrogen status. New Phytologist, 165, 227-241.

Roy, B. A., \& Kirchner, J. W. (2000). Evolutionary dynamics of pathogen resistance and tolerance. Evolution, 54, 51-63.

Scholler, M. (1994). Puccinia lagenophorae in Germany: Observations on colonization, distribution and ecology. Verhandlungen des Botanischen Vereins von Berlin und Brandenburg, 127, 177-189.
Shipley, B. (2000). Plasticity in relative growth rate and its components following a change in irradiance. Plant, Cell and Environment, 23, 1207-1216.

Shipley, B. (2002). Trade-offs between net assimilation rate and specific leaf area in determining relative growth rate: Relationship with daily irradiance. Functional Ecology, 16, 682-689.

Stowe, K. A. (1998). Experimental evolution of resistance in Brassica rapa: Correlated response of tolerance in lines selected for glucosinolate content. Evolution, 52, 703-712.

Stowe, A. E., \& Holt, J. S. (1988). Comparison of triazineresistant and triazine-susceptible biotypes of Senecio vulgaris and their F1 hybrids. Plant Physiology, 87, 183-189.

Strauss, S. Y., \& Agrawal, A. A. (1999). The ecology and evolution of plant tolerance to herbivory. Trends in Ecology and Evolution, 14, 179-185.

Tiffin, P. (2000). Mechanisms of tolerance to herbivore damage: What do we know? Evolutionary Ecology, 14, 523-536.

Zar, J. H. (1984). Biostatistical analysis. New Jersey, USA: Prentice-Hall International. 